ISSN 1678-3921

Journal homepage: www.embrapa.br/pab

For manuscript submission and journal contents, access: www.scielo.br/pab
Elayne Cristina Gadelha Vasconcelos ${ }^{(1 凶)(D),}$ Magno José Duarte Cândido(2) (D), Roberto Cláudio Fernandes Franco Pompeu $^{(3)}$ (iD,

Ana Clara Rodrigues Cavalcante ${ }^{(3)}$ (iD) and Marcos Neves Lopes ${ }^{(4)}$ (iD

(1) Instituto Federal de Educação, Ciência e Tecnologia do Piauí, Campus Cocal, Rodovia Piauí-213, Km 22, Zona Rural, CEP 64235-000 Cocal, PI, Brazil.

E-mail: elaynegadelha@gmail.com

(2) Universidade Federal do Ceará, Centro de Ciências Agrárias, Departamento de Zootecnia, Avenida Mister Hull, № 2.977, Bloco 808, Pici, CEP 60440-554 Fortaleza, CE, Brazil.

E-mail: magno@ufc.br

(3) Embrapa Caprinos e Ovinos, Rua Estrada Sobral-Groaíras, s/no, Zona Rural, CEP 62010-970 Sobral, CE, Brazil.

E-mail: roberto.pompeu@embrapa.br, ana.clara@embrapa.br

(4) Instituto Federal de Educação, Ciência e Tecnologia do Piauí, Campus Valença do Piauí, Avenida Joaquim Manuel, Área Urbana, CEP 64300-000 Valença do Piauí, $\mathrm{PI}$, Brazil.

E-mail:marcos.neves@ifpi.edu.br

$\bowtie$ Corresponding author

Received

January 18, 2019

Accepted

June 12, 2020

How to cite

VASCONCELOS, E.C.G.; CÂNDIDO, M.J.D.; POMPEU, R.C.F.F.; CAVALCANTE, A.C.R.; LOPES, M.N. Morphogenesis and biomass production of 'BRS Tamani' guinea grass under increasing nitrogen doses. Pesquisa Agropecuária Brasileira, v.55, e01235, 2020. DOI: https://doi.org/10.1590/S1678-3921. pab2020.v55.01235.

\section{Morphogenesis and biomass production of 'BRS Tamani' guinea grass under increasing nitrogen doses}

\begin{abstract}
The objective of this work was to evaluate the morphogenic and structural characteristics of Megathyrsus maximus 'BRS Tamani', subjected to increasing nitrogen doses, as well as the components of its biomass. The experiment was carried out in a randomized complete block design with four treatments $\left(0,300,600\right.$, and $1,200 \mathrm{~kg} \mathrm{ha}^{-1} \mathrm{~N}$ per year) and three replicates, in 12 experimental units of $12.5 \mathrm{~m}^{2}$ each. The evaluations were performed in the rest period of the pasture, after defoliation to a residual leaf area index of 1.0, until the pasture reached the number 3.0 of new leaves produced per tiller. Leaf and stem elongation rates increased with the increment in $\mathrm{N}$ doses up to $1,200 \mathrm{~kg} \mathrm{ha}^{-1} \mathrm{~N}$ per year. There was a decreasing linear response for phyllochron and leaf life span. Increases of $704 \%$ were observed for the harvestable green leaf biomass, at the dose equivalent to $1,200 \mathrm{~kg} \mathrm{ha}^{-1} \mathrm{~N}$ per year. The biomasses of dead forage and harvestable stem were not affected by the $\mathrm{N}$ doses. Nitrogen fertilization shows a positive effect on the morphogenic, structural, and productive characteristics of 'BRS Tamani' guinea grass up to the dose equivalent to $1,200 \mathrm{~kg} \mathrm{ha}^{-1} \mathrm{~N}$ per year.
\end{abstract}

Index terms: Megathyrsus maximus 'BRS Tamani', harvestable green leaf biomass, leaf elongation rate, tiller population density.

\section{Morfogênese e produção de biomassa de capim 'BRS Tamani' manejado sob doses crescentes de nitrogênio}

Resumo - O objetivo deste trabalho foi avaliar as características morfogênicas e estruturais de Megathyrsus maximus 'BRS Tamani', submetido a doses crescentes de adubação nitrogenada, assim como os componentes de sua biomassa. $\mathrm{O}$ experimento foi realizado em delineamento de blocos ao acaso, com quatro tratamentos $\left(0,300,600\right.$ e $1.200 \mathrm{~kg} \mathrm{ha}^{-1}$ de $\mathrm{N}$ por ano) e três repetições, em 12 unidades experimentais de $12,5 \mathrm{~m}^{2}$ cada uma. As avaliações ocorreram ao longo do período de descanso do pasto, após a desfolhação para um índice de área foliar residual de 1,0, até o momento em que o pasto atingiu o número 3,0 novas folhas produzidas por perfilho. As taxas de alongamento foliar e de colmo aumentaram com o incremento das aplicações de $\mathrm{N}$ até a dose equivalente a $1.200 \mathrm{~kg} \mathrm{ha}^{-1}$ de $\mathrm{N}$ por ano. Houve resposta linear decrescente do filocrono e do tempo de vida das folhas. Incrementos de $704 \%$ foram observados na biomassa de folhas verdes passíveis de colheita, para a dose equivalente a $1.200 \mathrm{~kg} \mathrm{ha}^{-1} \mathrm{de} \mathrm{N}$ por ano. As biomassas de forragem morta $\mathrm{e}$ caule colhido não foram afetadas pelas doses de N. A adubação nitrogenada apresenta efeito positivo sobre as características morfogênicas, estruturais e 
produtivas do capim 'BRS Tamani' até a dose equivalente a $1.200 \mathrm{~kg} \mathrm{ha}^{-1}$ de N por ano.

Termos para indexação: Megathyrsus maximus 'BRS Tamani', biomassa foliar verde para colheita, taxa de alongamento foliar, densidade populacional de perfilhos.

\section{Introduction}

The areas of cultivated pasture have competed for space with other demands of the society for the food production of vegetal origin, as well as for the generation of energy and provision of environmental services (Thornton, 2010). These issues become more serious in regions with climate vulnerability, where some of the factors of production are made available in an erratic way, increasing the uncertainty of plant and animal productivity.

In this context, the intensive management of highyield forage species subjected to adequate nutrient levels is an important strategy to reduce the fluctuation of forage biomass throughout the year. However, understanding the morphophysiological mechanisms of plants, and their interaction with the environment, is essential for the definition of management strategies to guarantee the persistence of the pasture and its productive capacity (Lopes et al., 2013).

Morphogenesis defines the dynamics of generation and expansion of new plant organs in space, as well as their disappearance due to senescence (Chapman \& Lemaire, 1993). In the last few years, morphogenic characteristics have been used by several authors to evaluate the responses of forage plants to environment conditions, and also to determine rational strategies for grazing and pasture management (Silva et al., 2015).

The availability of nutrients and high-yield forage species are essential to the success of pasture productivity. However, they also depend on the morphophysiological mechanisms and their interaction with the environment to maintain the persistence and productive capacity of the pasture (Martuscello, et al., 2015).

Among macronutrients, nitrogen is considered the main one that guarantees productivity and persistence of the pasture. It also influences the morphogenic indices (leaf appearance and elongation, leaf senescence, and stem elongation), as well as the structural characteristics of the grasses (leaf size, tiller population density, and number of new leaves per tiller), which directly reflects on pasture quality (Cabrera-Bosquet et al., 2009; Santos et al., 2012; Gastal \& Lemaire, 2015). Nitrogen represents 20 to 40 $\mathrm{g} \mathrm{kg}^{-1}$ of the dry matter present in plant tissues (Taiz et al., 2017), so there is evidence that tropical grasses subjected to intensive management can respond to $\mathrm{N}$ doses of 1,800 kg ha-1 (Mello et al., 2008).

Megathyrsus maximus (Syn. Panicum maximum) 'BRS Tamani' has important attributes as a forage plant, with promising emergence of leaves and tillers, high nutritional value, and high productivity and vigor (BRS Tamani..., 2015). These characteristics are favorable to forage production systems. Thus, research on its adaptability and development for biomass production and accumulation is important for pasture-based production systems. However, more studies that contrast its productive characteristics are necessary to allow of a better understanding of this grass performance.

The forage biomass and the way it shows itself is a result of the forage production process. Forage production is based on the photosynthetic processes from the interception of the incident solar radiation, which depends on the leaf area index that is affected by abiotic factors and by the applied management that regulate the canopy structure. The knowledge on the biomass fractions produced in the pasture makes it possible to infer mainly on the quality of the pasture (Silva et al., 2015).

The objective of this work was to evaluate the morphogenic and structural characteristics of 'BRS Tamani' guinea grass subjected to increasing $\mathrm{N}$ doses fertilization, and its biomass components.

\section{Materials and Methods}

The experiment was carried out in pasture of Megathyrsus maximus (Jacq.) B.K.Simon \& Jacobs (Syn. Panicum maximum Jacq.) 'BRS Tamani', from July to December 2017, at the Universidade Federal do Ceará, in the Animal Science Department, NEEF/ $\mathrm{DZ} / \mathrm{CCA} / \mathrm{UFC}$, in the municipality of Fortaleza $\left(30^{\circ} 43^{\prime} 02^{\prime \prime} \mathrm{S}, 38^{\circ} 32^{\prime} 35^{\prime \prime} \mathrm{W}\right)$, in the state of Ceará, Brazil. According to the Köppen-Geiger's classification, the climate of the region is type Aw - tropical rainy.

A randomized complete block design with four plots ( $\mathrm{N}$ fertilization doses) and three replicates (blocks), totaling 12 experimental units of $12.5 \mathrm{~m}^{2}$ each $(2.5 \mathrm{x}$ 
$5.0 \mathrm{~m})$. The $\mathrm{N}$ fertilization was carried out in $\mathrm{N}$ doses per year as follows: $0 \mathrm{~kg} \mathrm{ha}^{-1} \mathrm{~N}$ per year; $300 \mathrm{~kg} \mathrm{ha}^{-1} \mathrm{~N}$ per year $\left(20.55 \mathrm{~kg} \mathrm{ha}^{-1} \mathrm{~N}\right.$ per cycle, or $0.822 \mathrm{~kg} \mathrm{ha}^{-1} \mathrm{~N}$ per day x 25 days of rest period); $600 \mathrm{~kg} \mathrm{ha}^{-1} \mathrm{~N}$ per year (36.17 $\mathrm{kg} \mathrm{ha}^{-1} \mathrm{~N}$ per cycle, or $1.644 \mathrm{~kg} \mathrm{ha}^{-1} \mathrm{~N}$ per day x 22 days of rest period; and $1,200 \mathrm{~kg} \mathrm{ha}^{-1} \mathrm{~N}$ per year (55.91 kg ha-1 $\mathrm{N}$ per cycle, or $3.289 \mathrm{~kg} \mathrm{ha}^{-1} \mathrm{~N}$ per day $\mathrm{x}$ 17 days of rest period).

The soil of the experimental area was classified as Argissolo Amarelo eutrófico (PAe) (Ultisol) (Santos et al., 2018). The soil analysis at 0-20 $\mathrm{cm}$ soil depth, carried out at the beginning of the experiment, showed the following chemical characteristics: $24.0 \mathrm{mg} \mathrm{dm}^{-3} \mathrm{P} ; 30.89 \mathrm{mg} \mathrm{dm}^{-3} \mathrm{~K}$; $1.44 \mathrm{cmol}_{\mathrm{c}} \mathrm{dm}^{-3} \mathrm{Ca}^{2+} ; 1.14 \mathrm{cmol}_{\mathrm{c}} \mathrm{dm}^{-3} \mathrm{Mg}^{2+} ; 14.50 \mathrm{~g} \mathrm{~kg}^{-1}$ organic matter; $7.0 \mathrm{cmol}_{\mathrm{c}} \mathrm{dm}^{-3}$ of base saturation; 5.2 $\mathrm{cmol}_{\mathrm{c}} \mathrm{dm}^{-3}$ of cation exchange capacity; $6.9, \mathrm{pH}$ in water; 10.9 ppm $\mathrm{Fe}^{2+} ; 0.4 \mathrm{mg} \mathrm{dm}{ }^{-3} \mathrm{Cu}^{2+} ; 8.3 \mathrm{mg} \mathrm{dm}{ }^{-3}$ $\mathrm{Zn}^{2+}$ and $11.9 \mathrm{mg} \mathrm{dm}^{-3} \mathrm{Mn}$. The soil correction was performed according to the recommendations for grasses with high productive potential (Alvarez V. et al., 1999). and are shown in Table 1.

At planting, the fertilization was applied on the planting rows according to the recommendations based on the soil analysis, in the following amounts: $50 \mathrm{~kg} \mathrm{ha}^{-1} \mathrm{P}_{2} \mathrm{O}_{5}$, corresponding to $250 \mathrm{~kg} \mathrm{ha}^{-1}$ of single superphosphate; $60 \mathrm{~kg} \mathrm{ha}^{-1} \mathrm{~K}_{2} \mathrm{O}$, corresponding to $100 \mathrm{~kg} \mathrm{ha}^{-1}$ of potassium chloride; and $50 \mathrm{~kg} \mathrm{ha}^{-1}$ of fritted trace elements (FTE BR-12-0.42 $\mathrm{kg} \mathrm{ha}^{-1} \mathrm{Cu}$, $1.0 \mathrm{~kg} \mathrm{ha}^{-1} \mathrm{Mn}, 4.5 \mathrm{~kg} \mathrm{ha}^{-1} \mathrm{Zn}, 1.95 \mathrm{~kg} \mathrm{ha}^{-1} \mathrm{~S}$, and 0.90 $\mathrm{kg} \mathrm{ha-1}$ B).

Guinea grass was planted on May $20^{\text {th }}, 2017$ by manual sowing in the row, with $0.25 \mathrm{~m}$ of space between rows. A sowing rate equivalent to 1,930 seed per $5 \mathrm{~m}$ row, or $5.95 \mathrm{~g}$ of pure viable seed was adopted, which is equivalent to $4.8 \mathrm{~kg} \mathrm{ha}^{-1}$.

The climatic data of the experimental period (Figure 1) were obtained at the meteorological station of the Universidade Federal do Ceará, located $0.5 \mathrm{~km}$ from the experimental area.
After sowing, on July $12^{\text {nd }}, 2017$, the canopy height was standardized to $10 \mathrm{~cm}$ height in all experimental units. The cutting was made with the aid of a lateral brushcutter, and the biomass residues were removed from the plots immediately after cutting.

The 'BRS Tamani' guinea grass pasture was managed withalow-pressuresprinklerirrigation(servicepressure $\leq 2.0 \mathrm{kgf} \mathrm{cm}^{-2}$ ), with fixed daily liquid amount of 6.8 $\mathrm{mm}$ per day, and $40 \mathrm{~min}$ irrigation time, in the morning, initially at $06: 00 \mathrm{~h}$, in order to guarantee the uniformity of the applied amount. At the beginning, the irrigation system was evaluated by pluviometers (Fabrimar S.A, Rio de Janeiro, RJ, Brazil) installed at $50 \mathrm{~cm}$ height, at $3.0 \times 3.0 \mathrm{~m}$ spacing, throughout the experimental area. This allowed of the check of the application uniformity of water amount in the experimental unit, and to determine the above mentioned parameters.

Phosphate, potassium, and micronutrients fertilization were carried out based on the soil analysis results. Nitrogen (urea) and potassium applications were split. Potassium was divided into five applications. Nitrogen fertilization was divided into two applications for each cycle, the first half was applied two days after the grass cut, and the second half was applied in the middle of the rest period. For all $\mathrm{N}$ applications, urea was diluted in water because of the small amount of fertilizer per application, which would make it difficult to apply it in the solid form. For the application, a backpack sprayer was used with a standardized water volume $(2,500 \mathrm{~mL})$, which was determined by a previously performed field test, seeking for a better standardization of application. After each fertilization, a $10 \mathrm{~min}$ irrigation was performed.

For the defoliation, a lateral brushcutter was used for cutting in all plots, at $16 \pm 0.34 \mathrm{~cm}$ height, which guaranteed the management goal recommended for the residue. This height was fixed for all evaluated doses, as determined in a pre-trial carried out at the establishment of the experiment, when the defoliation

Table 1. Chemical characteristics of the Argissolo Amarelo eutrófico soil in the experimental area, at $0-20 \mathrm{~cm}$ soil depth, in the beginning of the experiment ${ }^{(1)}$.

\begin{tabular}{|c|c|c|c|c|c|c|c|c|}
\hline $\mathrm{P}$ & $\mathrm{K}$ & $\mathrm{Ca}^{2+}$ & $\mathrm{Mg}^{2+}$ & \multirow{2}{*}{$\begin{array}{c}\mathrm{pH} \\
\mathrm{H}_{2} \mathrm{O}\end{array}$} & $\mathrm{Al}^{3+}$ & SB & $\mathrm{CEC}$ & \multirow{2}{*}{$\begin{array}{c}\mathrm{OM} \\
\left(\mathrm{g} \mathrm{kg}^{-1}\right)\end{array}$} \\
\hline 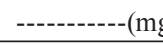 & - n-- & \multicolumn{2}{|c|}{ 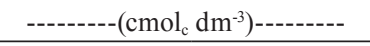 } & & $--\cdot-$ & $--\left(\mathrm{cmol}_{\mathrm{c}} \mathrm{dm}^{-3}\right)$ & -------- & \\
\hline 24.0 & 30.89 & 1.44 & 1.14 & 6.9 & 0.0 & 7.0 & 5.2 & 14.5 \\
\hline Intermediate & Low & Intermediate & Good & Weak acidity & & Intermediate & Low & Low \\
\hline$(21.1-30.0)$ & $(16-40)$ & $(1.21-2.40)$ & $(0.91-1.50)$ & $(6.1-6.9)$ & & $(1.81-3.60)$ & $(1.61-4.30)$ & $(7-20)$ \\
\hline
\end{tabular}

(1)Interpretation of the soil analysis according to Alvarez V. et al. (1999). SB, sum of bases; CEC, cation exchange capacity; OM, organic matter. 
and height monitoring were performed with the aid of a graduated ruler, as well as the residual leaf area index (LAI), through the interception of photosynthetically active radiation (PAR/LAI) in a portable PAR (Accupar LP-80 model, Decagon Devices, Pullman, Washington, USA). Six crossed readings (two per sampling spot, totaling three spots) were made per plot, by placing the equipment above the canopy and just below the last layer of green leaf blades.

All evaluations were performed between the pasture cuttings after defoliation to a 1.0 LAI. The adopted rest period was 3.0 new leaves produced per tiller, as determined in a pre-trial, when the experiment started and the treatment that received the dose equivalent to $1,200 \mathrm{~kg} \mathrm{ha}^{-1} \mathrm{~N}$ per year was considered the reference to determine $95 \%$ of the interception of photosynthetically active radiation (IPAR). This period is the ideal moment for defoliation, which guarantees the maximization of biomass accumulation rate.

For the measurement of the biomass flow variables, two clumps were marked per experimental unit, and three tillers were selected from each clump. Evaluations started three days after the defoliation, and they were repeated every three days. Elongation, emergence and senescence of leaves, and stem elongation were recorded. The length of the emergent leaf blade was measured from its apex to the ligule of the last expanded leaf; and the length of each expanded leaf blade was recorded by measuring the distance from its ligule to its apex. The senescent portion length was obtained by the difference between the total leaf length, at the time of the expansion, and the length of the still green portion. The stem elongation was obtained by the difference between the distances from the ligule of the last expanded leaf to the base of the tiller in the first and last readings, divided by the observation period.

The following indices were estimated: leaf elongation rate (LER), which refers to the average elongation/day of leaf blades of the tiller, during the rest period; leaf appearance (phyllochron) rate (LAR), obtained from the division of the number of leaves that appeared during the evaluation period by the evaluation period in days; stem elongation rate (SER), which refers to the daily average elongation of the sheaths, pseudo stem, and true stem of the tiller, during the rest period; BSR and TSR, which express the senescence rate of leaf blades formed before defoliation, generally formed by leaves sheared by the remaining cut and the

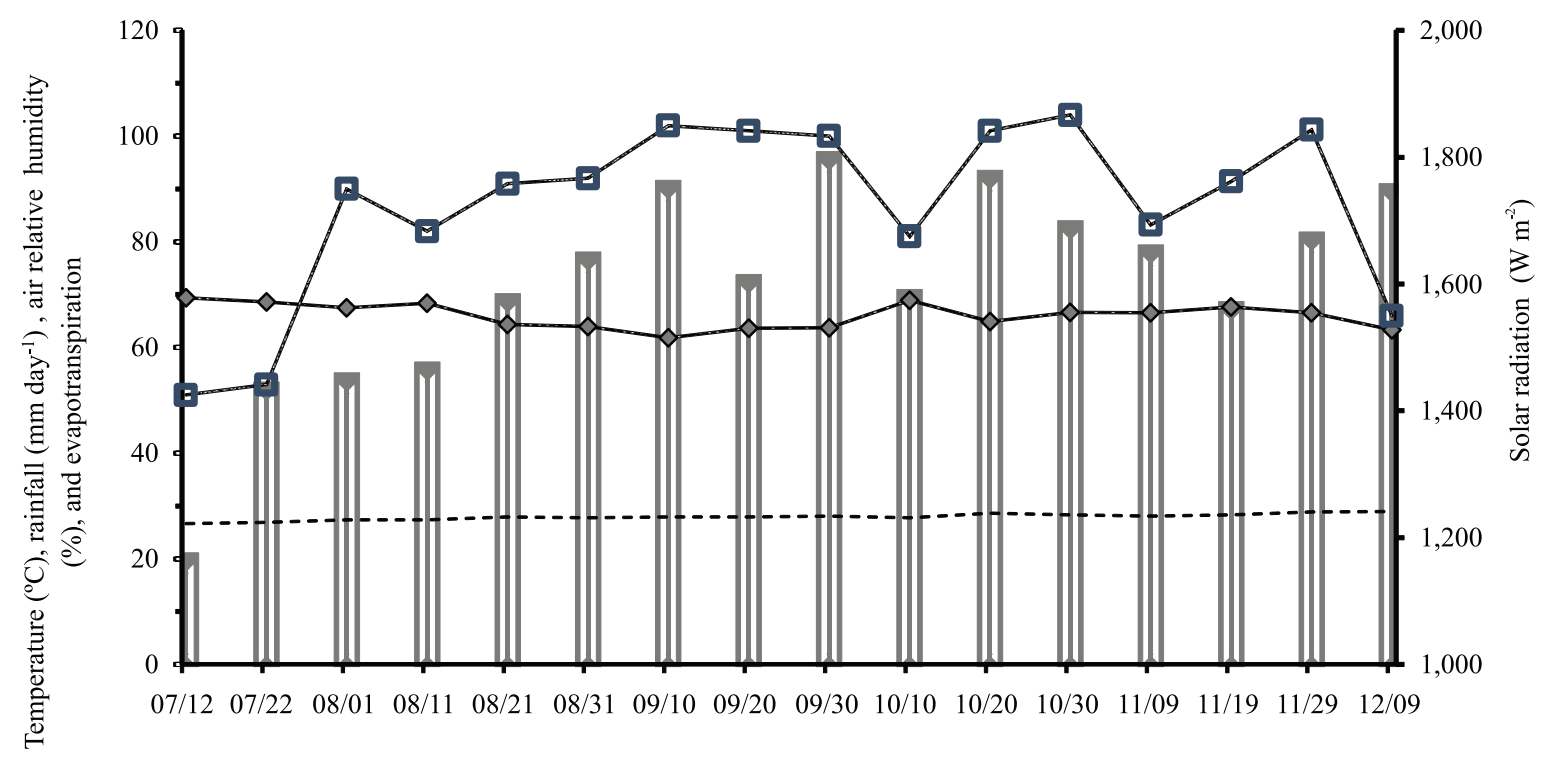

Experimental Period

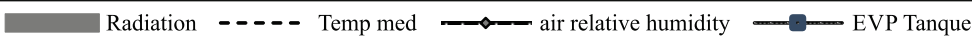

Figure 1. Averages of temperature, rainfall, air relative humidity, solar radiation, and evapotranspiration (EVP), during the experimental period in 2017, collected at the meteorological weather station of the Universidade Federal do Ceará, in the municipality of Fortaleza, in the state of Ceará, Brazil. Note: Only a rainfall event of $57.6 \mathrm{~mm}$ was recorded in the period from $07 / 12 / 2017$ to $07 / 16 / 2017$. 
total leaf blade senescence rate of the subsequent cut, respectively.

For the measurements of the canopy structure and its components, the following evaluations were performed at the end of the rest period: leaf area index (LAI), estimated through the PAR/LAI by evaluating six spots, in the average condition of the plot and thus obtaining the mean LAI of the paddock; estimated canopy height, which was obtained by measuring the canopy height in 30 points, using a retractable graduated rod; tiller population density (TPD), which was estimated by counting the live tillers within a 0.25 x $0.25 \mathrm{~m}$ frame in two spots of the experimental unit; number of new leaves/tiller, determined by counting as 1.0 the number of new expanded leaves per tiller as those in which the ligule was already exposed, and by counting as 0.5 the number of leaves when the ligule was not yet exposed; the sampling was performed for 10 tillers randomly.

Harvestable dead forage biomass (HDFB), harvestable green forage biomass (HGFB), harvestable green leaf biomass (HGLB), harvestable green stem biomass (HGSB), and leaf/stem ratio (L/S) were estimated by cutting. In each experimental unit, two samples of $0.50 \times 0.50 \mathrm{~m}$ were extracted from the soil surface, at $16 \mathrm{~cm}$ height, and taken to the laboratory for the separation of living material from the dead one. Then in the living material, leaf blades were separated from the stems. All these fractions were weighed, dried in a forced-air ventilation oven, at $55^{\circ} \mathrm{C}$, until reaching constant weight, and weighed again. From the total dry weight and fractions, the harvestable forage biomass was quantified.

Data were tested by the analyses of variance and regression. The analysis of variance model included the fixed effect of the $\mathrm{N}$-fertilization doses and the random effect of the evaluation cycles. The choice of linear and nonlinear models was based on the significance of the respective coefficients and on the coefficient of determination, using the Student's t-test, at $5 \%$ probability. The procedure REG of the software SAS (SAS Institute Inc, Cary, NC, USA) was used for the statistical analyses.

\section{Results and Discussion}

The leaf elongation rate (LER) increased because of the application of high doses of $\mathrm{N}$ fertilization
(Figure 2 A). An increasing linear response was observed for LER, with estimated mean values of 2.53 and $5.01 \mathrm{~cm}$ per tiller per day, at the doses of 0.0 and $1,200 \mathrm{~kg} \mathrm{ha}^{-1} \mathrm{~N}$ per year, respectively. The increment of $0.00206 \mathrm{~cm}$ per tiller per day was found for each kilogram of $\mathrm{N}$ added.

This increase confirms the $\mathrm{N}$ effect on LER (Lopes et al., 2013, 2014; Martuscello et al., 2015, 2019). The effect of $\mathrm{N}$ for fertilization on 'Massai' grass (Panicum maximum $x$ Panicum infestum) showed an increasing linear response for LER with estimated values of 2.32 and $5.14 \mathrm{~cm}$ per tiller per day, at the doses 0.0 and $1,200 \mathrm{~kg} \mathrm{ha}^{-1} \mathrm{~N}$ per year, respectively, representing $121.55 \%$ increment for the dose $1,200 \mathrm{~kg} \mathrm{ha}^{-1} \mathrm{~N}$ per year, in comparison to the absence of $\mathrm{N}$ fertilization (Lopes et al., 2013). These values are similar to those found in the present study.

LER is a variable directly related to the production of dry forage biomass (Lopes et al., 2013), since an increase of this variable provides an increment in the proportion of leaves, ensuring a greater accumulation of expanded green biomass.

The stem elongation rate (SER) increased with the elevation of the $\mathrm{N}$ doses, showing estimates of 0.056 and $0.15 \mathrm{~cm}$ per tiller per day, at 0.0 and $1,200 \mathrm{~kg} \mathrm{ha}^{-1}$ $\mathrm{N}$ per year, respectively (Figure $2 \mathrm{~B}$ ). The increment of $0.000076 \mathrm{~cm}$ per tiller per day was observed for each kilogram of $\mathrm{N}$ added. The $\mathrm{N}$ impact on the SER of 'BRS Tamani' guinea grass was lower than its impact on the LER (Figure 2 A), which shows a genetic predisposition of this grass to produce biomass in favor of the green leaf blades, which could have a positive impact on the efficiency of forage utilization by grazing animals. The $\mathrm{N}$ fertilization had no effect on the total leaf senescence rate (TSR), with mean values of $0.363 \pm 0.100 \mathrm{~cm}$ per tiller per day. This value is considered low in comparison to other tropical grasses of the same genus subjected to similar doses of fertilizer (Lopes et al., 2013, 2014; Martuscello et al., 2015, 2019).

The posterior leaf senescence rate represents the death of leaf tissues produced after the last grazing, therefore, it would come from the death of part of the new leaves formed, which would characterize an inadequate frequency of defoliation; however, that was not the case (Cândido et al., 2006).

A decreasing linear response was observed for phyllochron (Phy, leaf appearance) and leaf life span 
(LLS) in consequence of the $\mathrm{N}$ doses applied for fertilization (Figures $2 \mathrm{C}$ and D). The reductions of 0.0037 days for Phy, and 0.00815 days for LLS were observed for each kilogram of $\mathrm{N}$ added. The response of the phyllochron was similar to the results found in the literature (Lopes et al., 2014; Martuscello et al., 2015, 2019). These results confirm the $\mathrm{N}$ importance to reduce the time required for the appearance of successive leaves in the tiller, especially its effect on LER, which consequently gives the plant a greater ability to regrow after defoliation, and, therefore, the fast recovery of its photosynthetic apparatus (Martuscello et al., 2006).

The response pattern of LLS can be explained physiologically because in the absence of $\mathrm{N}$ fertilization the plants tend to remain a longer time with their live leaves, which is a compensatory effect to maintain the photosynthetic capacity of the canopy, since there is no emergence and expansion of new leaves and, consequently, tiller population density is low (Martuscello et al., 2006).

The management with the highest dose of $\mathrm{N}$ guaranteed a greater renewal of leaf tissues. The LLS allows of the management with a defoliation frequency that maximizes the efficiency of use of the biomass of expanded forage, reducing losses by senescence (Basso et al., 2010; Paiva et al., 2011).

The $\mathrm{N}$ doses promoted significant changes in the following variables: canopy height; leaf area index;
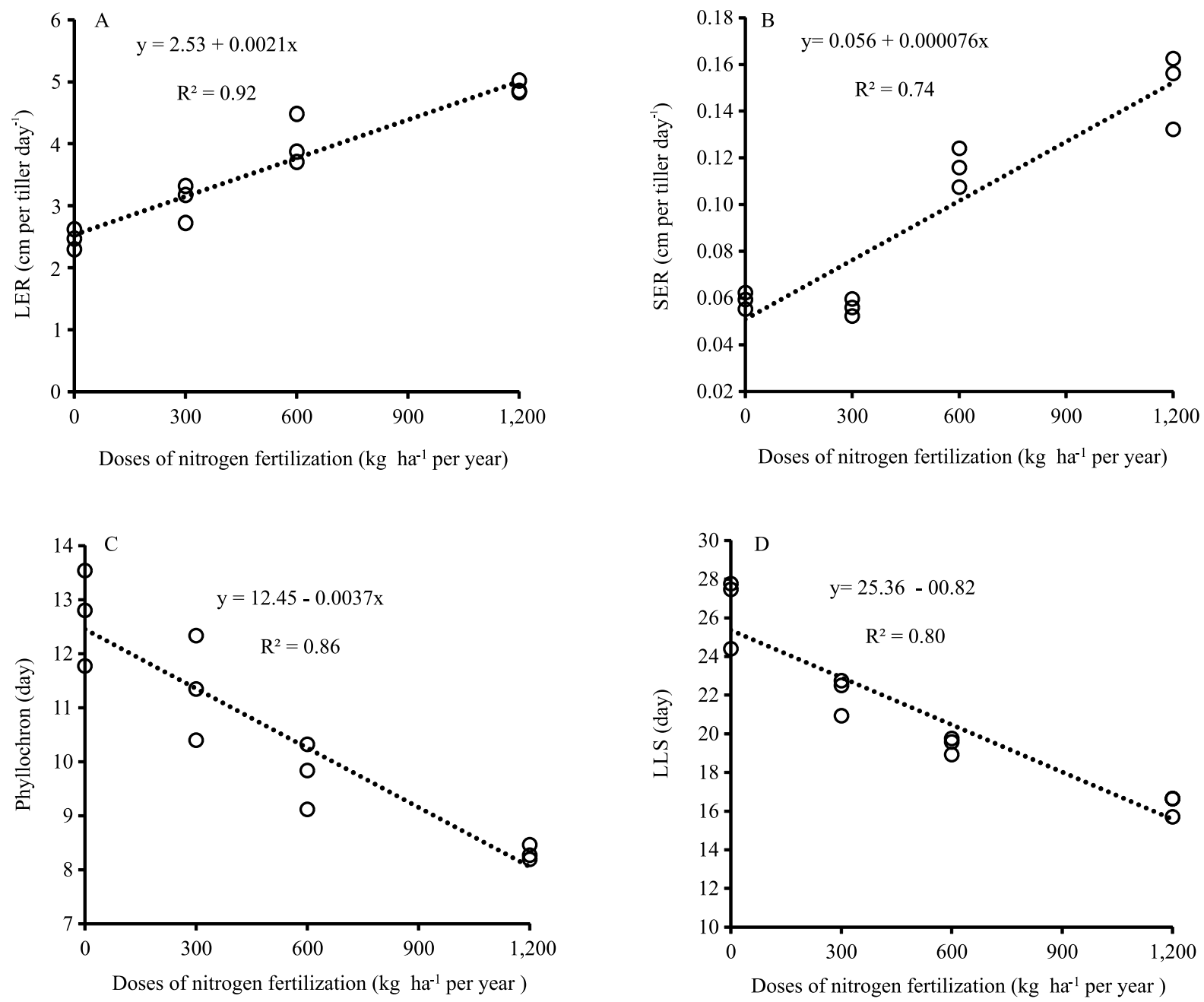

Figure 2. Characteristics of irrigated pasture of Megathyrsus maximus 'BRS Tamani' managed with increasing doses of nitrogen fertilization: (A) LER, leaf elongation rate; (B) SER, stem elongation rate; (C) Phyllochron; and (D), LLS, leaf life span. 
interception of the photosynthetically active radiation; total harvestable forage biomass, harvestable green forage biomass, harvestable green leaf biomass and tiller population density (Figures 3 and 4). The $\mathrm{N}$ fertilization caused a decreasing linear response only for the rest period (Figure $3 \mathrm{~A}$ ). The rest period showed values estimated in 29 and 17 days, at 0.0 and 1,200 $\mathrm{kg} \mathrm{ha}^{-1} \mathrm{~N}$ per year, respectively. This response is due to the management adopted for the pasture, for which the rest period varied according to each dose evaluated, conferring shorter rest periods to the higher doses and vice versa.

An increasing linear response was observed for canopy height, that showed values estimated in 24.47
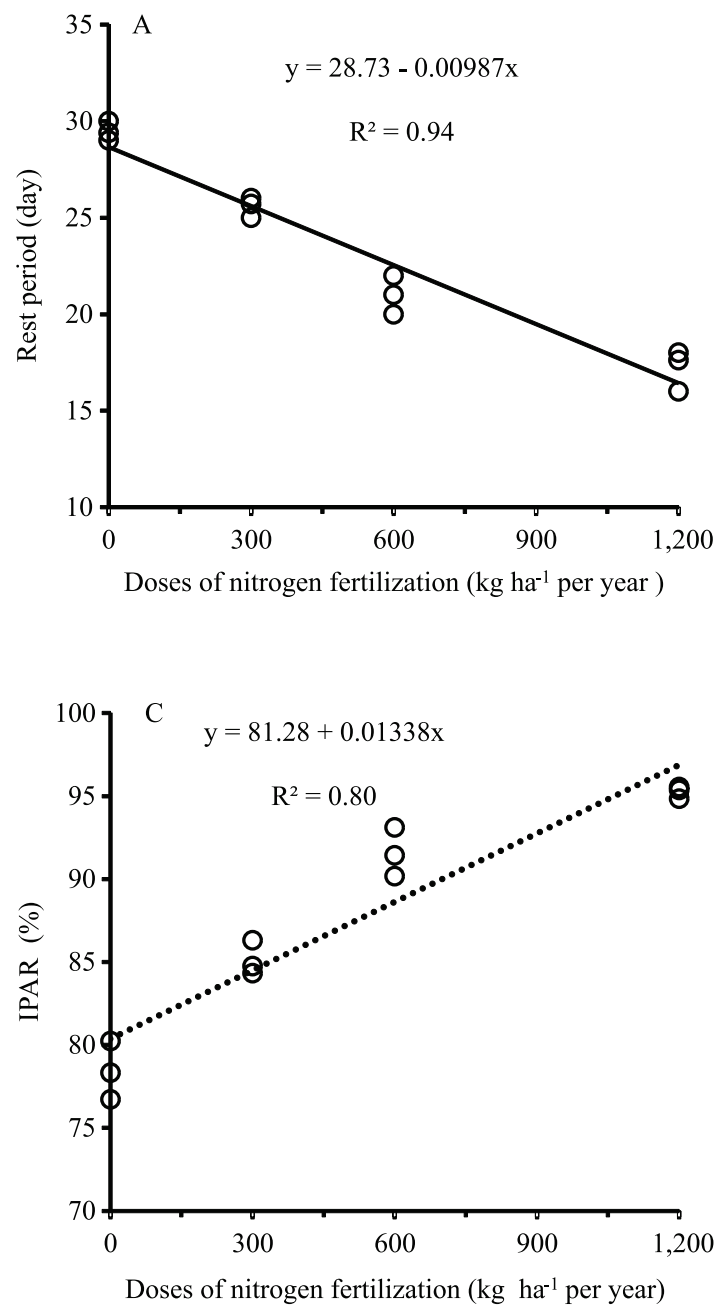

and $34.07 \mathrm{~cm}$ at 0.0 and $1,200 \mathrm{~kg} \mathrm{ha}^{-1} \mathrm{~N}$ per year, respectively (Figure $3 \mathrm{~B}$ ). This behavior was similar to SER in this study, for which 0.056 and $0.14 \mathrm{~cm}$ per tiller per day were obtained with the doses 0.0 and 1,200 $\mathrm{kg} \mathrm{ha}^{-1} \mathrm{~N}$ per year, respectively. The recommended residual leaf area index of 1.0 allowed of the control of stem elongation, since the increasing response verified in this study is low, is comparison to the cumulative harvestable green leaf biomass (HGLB).

LAI and IPAR showed a linear response according to the $\mathrm{N}$ fertilizer applied, with estimated values of 81.28 and $95.36 \%$ (IPAR) and 3.37 and 7.09 (LAI) at 0.0 and $1,200 \mathrm{~kg} \mathrm{ha}^{-1} \mathrm{~N}$ per year, respectively (Figure $3 \mathrm{C}$ and D). The forage biomass is determined by the amount
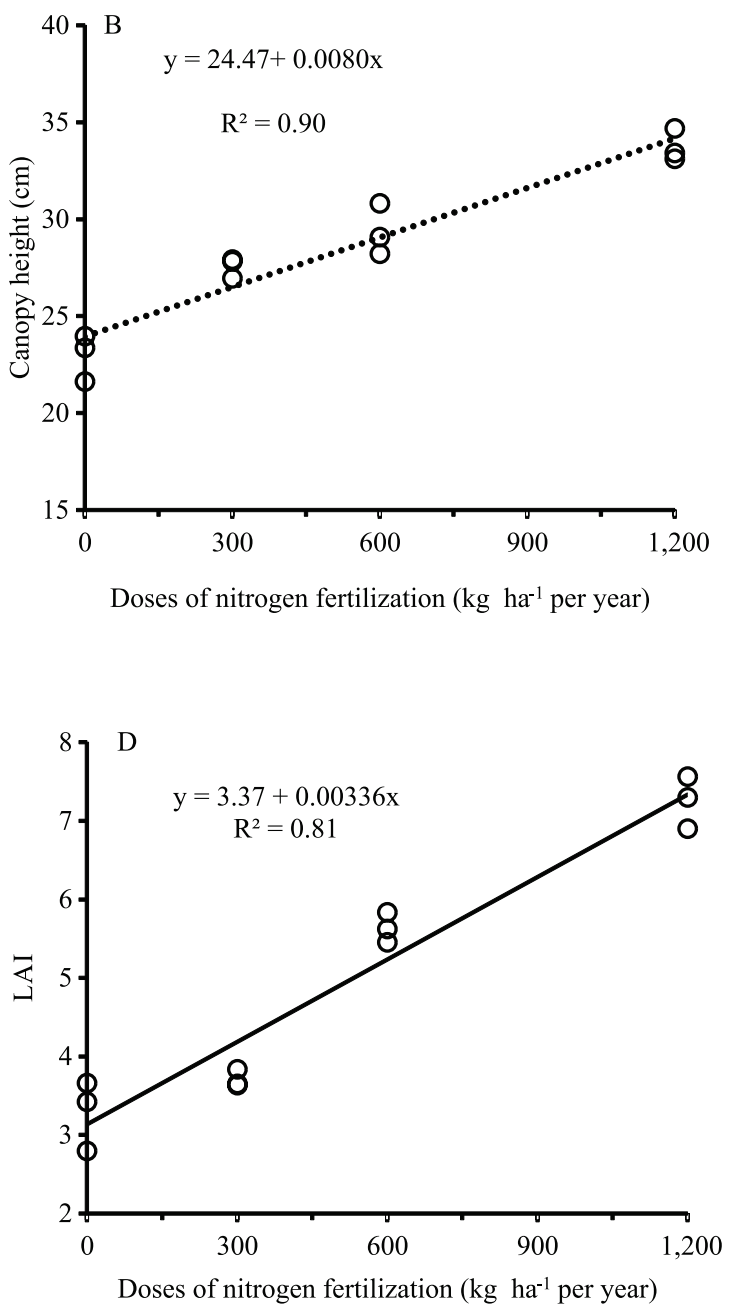

Figure 3. Irrigated pasture of Megathyrsus maximus 'BRS Tamani' managed with increasing doses of nitrogen fertilization. A, rest period; B, canopy height; C, IPAR, interception of the photosynthetically active radiation; and D, LAI, leaf area index. 
of light that is intercepted by the canopy. As the LAI increased, IPAR consequently increased, promoting a better efficiency of use of the photosynthetically active radiation and accelerating the growth rate, under favorable environmental conditions, which resulted in biomass accumulation (Stewart et al., 2003).

LAI is an indicator of the production potential of forage biomass, which is closely linked to the efficiency of using incident solar energy through the photosynthetic process (Lopes et al., 2013). The $\mathrm{N}$ absence affected the production of leaf blades, consequently resulting in a lower LAI.

The values of 914.24 and 2,178.24 $\mathrm{kg} \mathrm{ha}^{-1}$ per cycle of HTFB (Figure 4 A) were observed at the doses 0.0 and
1,200 $\mathrm{kg} \mathrm{ha}^{-1} \mathrm{~N}$ per year, respectively. The production increase of 'BRS Tamani' biomass, with the increasing doses of $\mathrm{N}$, is explained by the $\mathrm{N}$ participation as a controlling agent of the processes of growth and development of the plants that favors a greater biomass production through the $\mathrm{CO}_{2}$ fixation. Other studies report such response for this variable due to the high-N doses fertilization (Braz et al., 2011; Martuscello et al., 2015, 2019; Lopes et al., 2019).

The HGFB showed estimated values of 874.64 and $2,127.45 \mathrm{~kg} \mathrm{ha}^{-1}$ per cycle, while the HGLB showed estimated values of 875.60 and $2,118.80 \mathrm{~kg} \mathrm{ha}^{-1}$ per cycle, at 0.0 and $1,200 \mathrm{~kg} \mathrm{ha}^{-1} \mathrm{~N}$ per year, respectively (Figure 4 B and C). The HGLB increased 704\% in

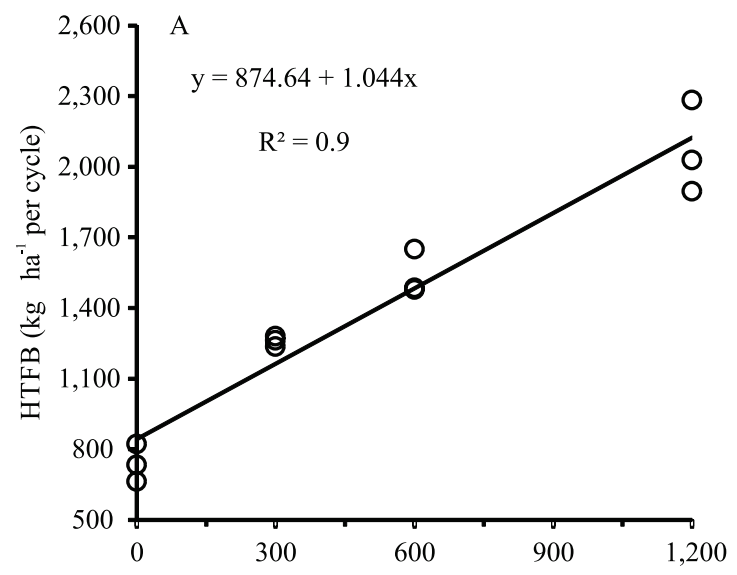

Doses of Nitrogen fertilization ( $\mathrm{kg} \mathrm{ha}^{-1}$ per year)

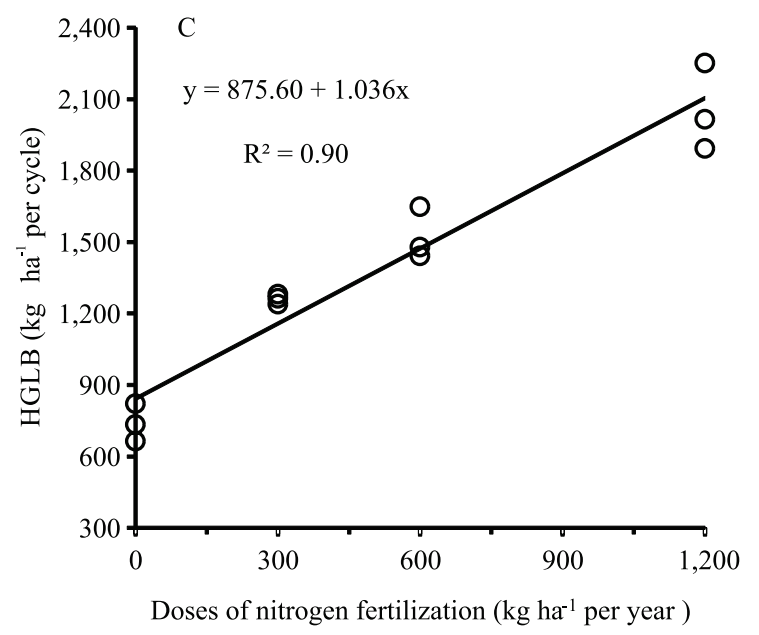

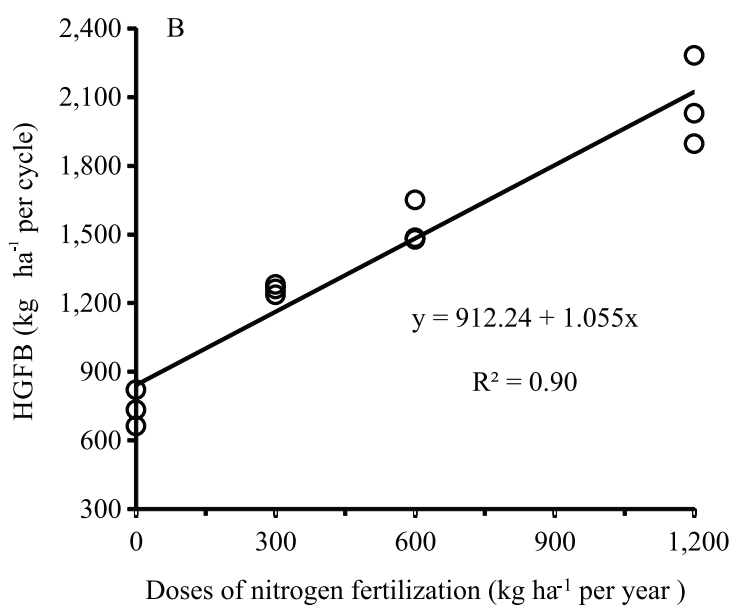

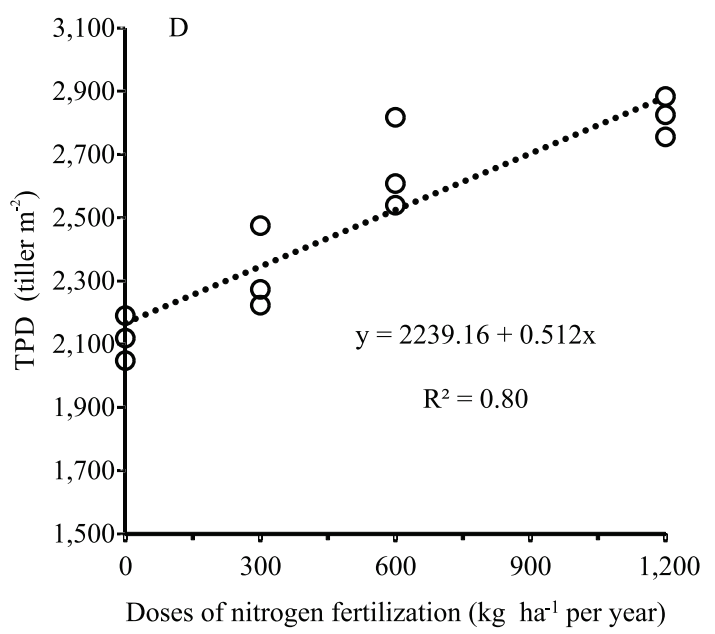

Figure 4. Biomass components of an irrigated pasture of Megathyrsus maximus 'BRS Tamani' managed with increasing doses of nitrogen fertilization: A, HTFB, harvestable total forage biomass; B, HGFB, harvestable green forage biomass; C, HGLB, harvestable green leaf biomass; and D, TPD, tiller population density. 
comparison of the dose $1,200 \mathrm{~kg} \mathrm{ha}^{-1} \mathrm{~N}$ per year with the dose $0.0 \mathrm{~kg} \mathrm{ha}^{-1} \mathrm{~N}$ per year. These values showed and increment of $27,350.04 \mathrm{~kg} \mathrm{ha}^{-1}$ of the biomass of leaf blades, at the dose $1,200 \mathrm{~kg} \mathrm{ha}^{-1} \mathrm{~N}$ per year, in comparison to the dose $0.0 \mathrm{~kg} \mathrm{ha}^{-1} \mathrm{~N}$ per year. The fertilization provided a biomass increment of 103.66 $\mathrm{kg}$ of green leaf blade for each kilogram of $\mathrm{N}$ added.

The $\mathrm{N}$ dose equivalent to $1,200 \mathrm{~kg} \mathrm{ha}^{-1} \mathrm{~N}$ per year allowed of a production of 23,960.64 $\mathrm{kg} \mathrm{ha}^{-1}$ of HGLB (Figure $4 \mathrm{C}$ ), during the evaluation period of 180 days; however, the dose $0.0 \mathrm{~kg} \mathrm{ha}^{-1} \mathrm{~N}$ resulted in 5,247.84 $\mathrm{kg} \mathrm{ha}^{-1}$ of HGLB during the same period. This result indicates an increment of $18,712.80 \mathrm{~kg} \mathrm{ha}^{-1}$, which confirms the $\mathrm{N}$ effect on productive forage grasses with high capacity of response to $\mathrm{N}$ fertilization, thus, potentializing and maximizing the leaf biomass production, increasing the carrying capacity of the pasture. The proportion of leaf blades in the forage canopy is very important, as it is the substrate of preferential, nutritional quality in animal feed (Freitas et al., 2012; Rodrigues et al., 2012). It is worth mentioning that the variables HGFB and HGLB were affected not only by the $\mathrm{N}$ fertilization, but also by the high temperature of the environment that stimulates leaf elongation, associated with the water availability through irrigation.

This result is also related to the high rates of LER (Figure $2 \mathrm{~A}$ ). This morphogenic variable shows a high correlation with the biomass of leaf blades (Lopes et al., 2013, 2014, 2019; Martuscello et al., 2015, 2019). Nitrogen acts positively on LER, affecting the photosynthetically active leaf area, accelerating the canopy recovery after defoliation.

No effect of could be observed for $\mathrm{N}$ doses on harvestable dead forage biomass (HDFB) and harvestable green stem biomass (HGSB), for which mean values were $44.12 \pm 16.18$ and $2.27 \pm 1.82 \mathrm{~kg} \mathrm{ha}^{-1}$ per cycle, respectively. This fact can be attributed to the high-tiller population density and, possibly, to the maintenance of a suitable residual LAI (1.0). This result indicates that the recommended management goal provides a better pasture vigor and faster regrowth as a nitrogen effect, increasing the tiller population, and guaranteeing the persistence and perenniality of the pasture. The appropriate LAI should favor the growth of the plant, without compromising its reserves, and minimizing stem elongation and senescence.

An increasing linear response was observed for the tiller population density (TPD) (Figure $4 \mathrm{D}$ ).
The highest- $\mathrm{N}$ dose fertilization, equivalent to 1,200 $\mathrm{kg} \mathrm{ha} \mathrm{a}^{-1} \mathrm{~N}$ per year, provided an increment of $21.54 \%$, in comparison to the absence of $\mathrm{N}$ fertilization, with values estimated in 2,239 and 2,853 tillers $\mathrm{m}^{-2}$ at 0.0 and $1,200 \mathrm{~kg} \mathrm{ha}^{-1} \mathrm{~N}$ per year, respectively (Figure 4 D). 'BRS Tamani' guinea grass has a high capacity of response to $\mathrm{N}$, and it is likely that the absence of this nutrient promotes a reduction of the appearance of new tillers (Pereira et al., 2010). Possibly, the greater frequency of cuts had also a positive effect on the activation of meristematic tissues (axillary buds).

The leaf/stem ratio was not affected by the $\mathrm{N}$ fertilization and showed a mean value of $1,422.29 \pm 37.50$, which can be explained by the increase of SER (Figure $2 \mathrm{~B}$ ), as the leaf biomass increased by the application of higher-N levels. Such fact reveals a favorable characteristic to this grass for grazing (Lopes et al., 2014). The values recorded for the grass under study are higher than those found for 'Massai' grass (4.33 \pm 0.92$)$, also under intensive management with increasing $\mathrm{N}$ levels up to $1,200 \mathrm{~kg} \mathrm{ha}^{-1} \mathrm{~N}$ per year (Lopes et al., 2019), which suggests that 'BRS Tamani' guinea grass is more responsive to $\mathrm{N}$, as well as to the high intensity and frequency of defoliation. 'BRS Tamani' showed higher cumulative biomass production of leaf blades, in a shorter interval between cuts than 'Massai', which is also an important parameter to maximize forage production and consequently animal production.

A high value of the leaf:stem ratio indicates a forage biomass with high-protein content (Mochel Filho et al., 2016) and digestibility because it has a great proportion of leaf blades that allows of a great voluntary intake of dry matter by the animals (Euclides et al., 1999). Furthermore, it suggests that 'BRS Tamani' shows a phenotypic plasticity favorable to the goal of defoliation management recommended of 3.0 new leaves produced by tiller, and a high intensity of defoliation, since it obtains a high density of tillers with a high frequency of cuts. Therefore, 'BRS Tamani' shows no beheading of meristems possibly located closer to the ground, which ensures the control of stem elongation.

Such response reflects the compensation of the leaf area, as a consequence of the evaluated $\mathrm{N}$ doses, in the comparison of the evaluated extremes. We observed that the recommended residual goal (LAI of 1.0) maintained an association with a residual height that remained within $16.0+0.34 \mathrm{~cm}$. Possibly, the application of the highest-N levels resulted in plants 
with smaller residual leaf blades and larger population of tillers, in contrast to the smallest $\mathrm{N}$ doses that resulted in plants with larger leaf blades associated with a smaller population of tillers. This fact shows that the pasture management is promising, in a way that allows of the maximization of both biomass accumulation and efficiency of use.

\section{Conclusion}

Nitrogen fertilization shows a positive linear effect on the morphogenic, structural, and productive characteristics of 'BRS Tamani' guinea grass (Megathyrsus maximus 'BRS Tamani') up to the dose equivalent to $1,200 \mathrm{~kg} \mathrm{ha}^{-1} \mathrm{~N}$ per year.

\section{Acknowledgments}

To Coordenação de Aperfeiçoamento de Pessoal de Nível Superior (Capes, Finance Code 001) and to Embrapa Caprinos e Ovinos, for the research funding; and to Núcleo de Ensino e Estudos em Forragicultura (NEEF), for the contribution with facilities and equipment.

\section{References}

ALVAREZ V., V.H.; NOVAIS, R.F. de; BARROS, N.F. de; CANTARUTTI, R.B.; LOPES, A.S. Interpretação dos resultados das análises de solos. In: RIBEIRO, A.C.; GUIMARÃES, P.T.G.; ALVAREZ V., V.H. (Ed.). Recomendações para o uso de corretivos e fertilizantes em Minas Gerais: $5^{\text {a }}$ aproximação. Viçosa: Comissão de Fertilidade do Solo do Estado de Minas Gerais, 1999. p.25-32.

BASSO, K.C.; CECATO, U.; LUGÃO, S.M.B.; GOMES, J.A.N.; BARBERO, L.M.; MOURÃO, G.B. Morfogênese e dinâmica do perfilhamento em pastos de Panicum maximum Jacq. cv. IPR-86 Milênio submetido a doses de nitrogênio. Revista Brasileira de Saúde e Produção Animal, v.11, p.976-989, 2010.

BRAZ, T.G. dos S.; FONSECA, D.M. da; FREITAS, F.P. de; MARTUSCELLO, J.A.; SANTOS, M.E.R.; SANTOS, M.V.; PEREIRA, V.V. Morphogenesis of Tanzania guinea grass under nitrogen doses and plant densities. Revista Brasileira de Zootecnia, v.40, p.1420-1427, 2011. DOI: https://doi.org/10.1590/ S1516-35982011000700004.

BRS Tamani, forrageira híbrida de Panicum maximum. Campo Grande: Embrapa Gado de Corte, 2015. Folder.

CABRERA-BOSQUET, L.; ALBRIZIO, R.; ARAUS, J.L.; NOGUÉS, S. Photosynthetic capacity of field-grown durum wheat under different $\mathrm{N}$ availabilities: a comparative study from leaf to canopy. Environmental and Experimental Botany, v.67, p.145152, 2009. DOI: https://doi.org/10.1016/j.envexpbot.2009.06.004.
CÂNDIDO, M.J.D.; SILVA, R.G. da; NEIVA, J.N.M.; FACÓ, O.; BENEVIDES, Y.I.; FARIAS, S.F. Fluxo de biomassa em capimtanzânia pastejado por ovinos sob três períodos de descanso. Revista Brasileira de Zootecnia, v.35, p.2234- 2242, 2006. DOI: https://doi.org/10.1590/S1516-35982006000800006.

CHAPMAN, D.F.; LEMAIRE, G. Morphogenetic and structural determinants of plant regrowth after defoliation. In: BAKER, M.J. (Ed.). Grassland for our world. Wellington: SIR Publishing, 1993. p.55-64.

EUCLIDES, V.P.B.; THIAGO, L.R.L. de S.; MARCELO, M.C.M.; OLIVEIRA, M.P. de. Consumo voluntário de forragem de três cultivares de Panicum maximum sob pastejo. Revista Brasileira de Zootecnia, v.28, p.1177-1185, 1999. DOI: https://doi.org/10.1590/S1516-35981999000600002.

FREITAS, F.P. de; FONSECA, D.M. da; BRAZ, T.G. dos S.; MARTUSCELLO, J.A; SANTOS, M.E.R. Forage yield and nutritive value of Tanzania grass under nitrogen supplies and plant densities. Revista Brasileira de Zootecnia, v.41, p.864-872, 2012. DOI: https://doi.org/10.1590/s1516-35982012000400006.

GASTAL, F.; LEMAIRE, G. Defoliation, shoot plasticity, sward structure and herbage utilization in pasture: review of the underlying ecophysiological processes. Agriculture, v.5, p.11461171, 2015. DOI: https://doi.org/10.3390/agriculture5041146.

LOPES, M.N.; CANDIDO, M.J.D.; POMPEU, R.C.F.F.; SILVA, R.G. da; CARVALHO, T.C.F. de; SOMBRA, W.A.; MORAIS NETO, L.B. de; PEIXOTO, M.J.A. Biomass flow in massai grass fertilized with nitrogen under intermittent stocking grazing with sheep. Revista Brasileira de Zootecnia, v.42, p.13-21, 2013. DOI: https://doi.org/10.1590/S1516-35982013000100003.

LOPES, M.N.; CÂNDIDO, M.J.D.; POMPEU, R.C.F.F.; SILVA, R.G. da; LACERDA, C.F. de; BEZERRA, F.M.L. Características morfogênicas de dois tipos de perfilhos e produção de biomassa do capim-massai adubado com nitrogênio durante o estabelecimento. Bioscience Journal, v.30, p.666-677, 2014. Suppl. 2.

LOPES, M.N.; CÂNDIDO, M.J.D.; POMPEU, R.C.F.F.; SILVA, R.G.; CARNEIRO, M.S.S.; MORAIS NETO, L.B.; PEIXOTO, M.J.A.; CARVALHO, T.C.F. Biomass components and structure of massai grass fertilized with nitrogen and grazed by sheep. Arquivo Brasileiro de Medicina Veterinária e Zootecnia, v.71, p.1411-1420, 2019. DOI: https://doi.org/10.1590/1678-4162-10051.

MARTUSCELLO, J.A.; FONSECA, D.M. da; NASCIMENTO JÚNIOR, D. do; SANTOS, P.M.; CUNHA, D. de N.F.V. da; MOREIRA, L. de M. Características morfogênicas e estruturais de capim-massai submetido a adubação nitrogenada e desfolhação. Revista Brasileira de Zootecnia, v.35, p.665-671, 2006. DOI: https://doi.org/10.1590/S1516-35982006000300006.

MARTUSCELLO, J.A.; RIOS, J.F.; FERREIRA, M.R.; ASSIS, J.A.; BRAZ, T.G.S.; CUNHA, D.N.F.V. Produção e morfogênese de capim BRS Tamani sob diferentes doses de nitrogênio e intensidades de desfolhação. Boletim de Indústria Animal, v.76, p.1-10, 2019. DOI: https://doi.org/10.17523/bia.2019.v76.e1441.

MARTUSCELLO, J.A.; SILVA, L.P. da; CUNHA, D. de N.F.V. da; BATISTA, A.C. dos S.; BRAZ, T.G. dos S.; FERREIRA, P.S. Adubação nitrogenada em capim-massai: morfogênese e

Pesq. agropec. bras., Brasília, v.55, e01235, 2020

DOI: 10.1590/S1678-3921.pab2020.v55.01235 
produção. Ciência Animal Brasileira, v.16, p.1-13, 2015. DOI: https://doi.org/10.1590/1089-68916i118730.

MELLO, S.Q.S.; FRANÇA, A.F. de S.; LANNA, A.C.; BERGAMASCHINE, A.F.; KLIMANN, H.J.; RIOS, L.C.; SOARES, T.V. Adubação nitrogenada em capim-mombaça: produção, eficiência de conversão e recuperação aparente do nitrogênio. Ciência Animal Brasileira, v. 9, p.935- 947, 2008.

MOCHEL FILHO, W. de J.E.; CARNEIRO, M.S. de S.; ANDRADE, A.C.; PEREIRA, E.S.; ANDRADE, AP. de; CÂNDIDO, M.J. da D.S.; MAGALHÃES, J.A.; RODRIGUEZ, B.H.N.; SANTOS, F.J. de S.; COSTA, N. de L. Produtividade e composição bromatológica de Panicum maximum cv. Mombaça sob irrigação e adubação azotada. Revista de Ciências Agrárias, v.39, p.81-88, 2016. DOI: https://doi.org/10.19084/RCA14154.

PAIVA, A.J.; SILVA, S.C. da; PEREIRA, L.E.T.; CAMINHA, F.O.; PEREIRA, P. de M.; GUARDA, V.D'Á. Morphogenesis on age categories of tillers in marandu palisadegrass. Scientia Agricola, v.68, p.626-631, 2011. DOI: https://doi.org/10.1590/S0103-90162011000600003.

PEREIRA, L.E.T.; PAIVA, A.J.; SILVA, S.C. da; CAMINHA, F.O.; GUARDA, V.D'Á.; PEREIRA, P. de M. Sward structure of marandu palisadegrass subjected to continuous stocking and nitrogen-induced rhythms of growth. Scientia Agricola, v.67, p.531-539, 2010. DOI: https://doi.org/10.1590/S0103-90162010000500006.

RODRIGUES, R.C.; LIMA, D.O.; PLESE, P.LM.; SCARAMUZZA, W.L.M.P.; UTSONOMYA, T.C.A.; SIQUEIRA de, J.C. Produção e morfofisiologia do capim Brachiaria brizantha cv. Xaraés sob doses de nitrogênio e fósforo. Revista Brasileira de Agropecuária Sustentável, v.2, p.124- 131, 2012.

SANTOS, H.G. dos; JACOMINE, P.K.T.; ANJOS, L.H.C. dos; OLIVEIRA, V.A. de; LUMBRERAS, J.F.; COELHO, M.R.; ALMEIDA, J.A. de; CUNHA, T.J.F.; OLIVEIRA, J.B. de. Sistema brasileiro de classificação de solos. 5.ed. rev. e ampl. Brasília: Embrapa, 2018. 356p.

SANTOS, M.E.R.; FONSECA, D.M. da; GOMES, V.M.; SILVA, S.P. da; SILVA, G.P.; CASTRO, M.R.S'.A. e. Correlações entre características morfogênicas e estruturais em pastos de capim braquiária. Ciência Animal Brasileira, v.13, p.49-56, 2012. DOI: https://doi.org/10.5216/cab.v13i1.13401.

SILVA, S.C. da; SBRISSIA, A.F.; PEREIRA, L.E.T. Ecophysiology of C4 forage grasses - understanding plant growth for optimising their use and management. Agriculture, v.5, p.598-625, 2015. DOI: https://doi.org/10.3390/agriculture5030598.

STEWART, D.W.; COSTA, C.; DWYER, L.M.; SMITH, D.L.; HAMILTON, R.I.; MA, B.L. Canopy Structure, Light Interception, and Photosynthesis in Maize. Agronomy Journal, v. 95, p.14651474, 2003. DOI: https://doi.org/10.2134/agronj2003.1465.

TAIZ, L.; ZEIGER, E.; MØLLER, I.M.; MURPHY, A. Fisiologia e Desenvolvimento Vegetal. 6.ed. Porto Alegre: Artmed, 2017. $888 \mathrm{p}$.

THORNTON, P.K. Livestock production: recent trends, future prospects. Philosophical Transactions of the Royal Society B: Biological Sciences, v.365, p.2853-2867, 2010. DOI: https://doi.org/10.1098/rstb.2010.0134. 